\title{
Carstensen, Thorsten
}

\section{Learning from John Ford. History, geography, and epic storytelling in the works of Peter Handke}

Zumhof, Tim [Hrsg.]; Johnson, Nicholas K. [Hrsg.]: Show, don't tell. Education and historical representations on stage and screen in Germany and the USA. Bad Heilbrunn : Verlag Julius Klinkhardt 2020, S. 131-159. - (Studien zur Deutsch-Amerikanischen Bildungsgeschichte / Studies in German-American Educational History)

Quellenangabe/ Reference:

Carstensen, Thorsten: Learning from John Ford. History, geography, and epic storytelling in the works of Peter Handke - In: Zumhof, Tim [Hrsg.]; Johnson, Nicholas K. [Hrsg.]: Show, don't tell. Education and historical representations on stage and screen in Germany and the USA. Bad Heilbrunn : Verlag Julius Klinkhardt 2020, S. 131-159 - URN: urn:nbn:de:0111-pedocs-205158 - DOI: 10.25656/01:20515

https://nbn-resolving.org/urn:nbn:de:0111-pedocs-205158

https://doi.org/10.25656/01:20515

in Kooperation mit / in cooperation with:

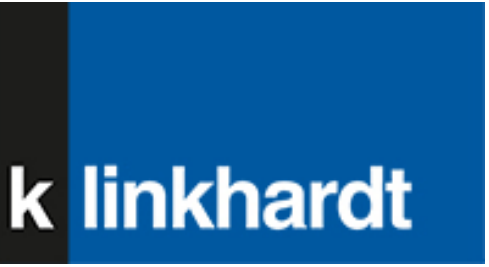

http://www.klinkhardt.de

\section{Nutzungsbedingungen}

Dieses Dokument steht unter folgender Creative Commons-Lizenz: http://creativecommons.org/licenses/by-nc-sa/4.0/deed.de - Sie dürfen das Werk bzw. den Inhalt unter folgenden Bedingungen vervielfältigen, verbreiten und öffentlich zugänglich machen sowie Abwandlungen und Bearbeitungen des Werkes bzw. Inhaltes anfertigen: Sie müssen den Namen des Autors/Rechteinhabers in der von ihm festgelegten Weise nennen. Dieses Werk bzw, der Inhalt darf nicht für kommerzielle Zwecke verwendet werden. Die neu entstandenen Werke bzw. Inhalte dürfen nur unter Verwendung von Lizenzbedingungen weitergegeben werden, die mit denen dieses Lizenzvertrages identisch oder vergleichbar sind.

Mit der Verwendung dieses Dokuments erkennen Sie die Nutzungsbedingungen an.

\section{Terms of use}

This document is published under following Creative Commons-License: http://creativecommons.org/licenses/by-nc-sa/4.0/deed.en - You may copy, distribute and transmit, adapt or exhibit the work in the public and alter, transform or change this work as long as you attribute the work in the manner specified by the author or licensor. You are not allowed to make commercial use of the work. If you alter, transform, or change this work in any way, you may distribute the resulting work only under this or a comparable license.

By using this particular document, you accept the above-stated conditions of use.

\section{Kontakt / Contact:}

peDOcs

DIPF | Leibniz-Institut für Bildungsforschung und Bildungsinformation Informationszentrum (IZ) Bildung

E-Mail: pedocs@dipf.de

Internet: www.pedocs.de

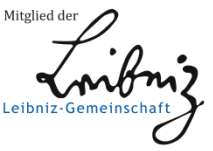




\section{Studien zur Deutsch-Amerikanischen}

Bildungsgeschichte / Studies in German-American Educational History

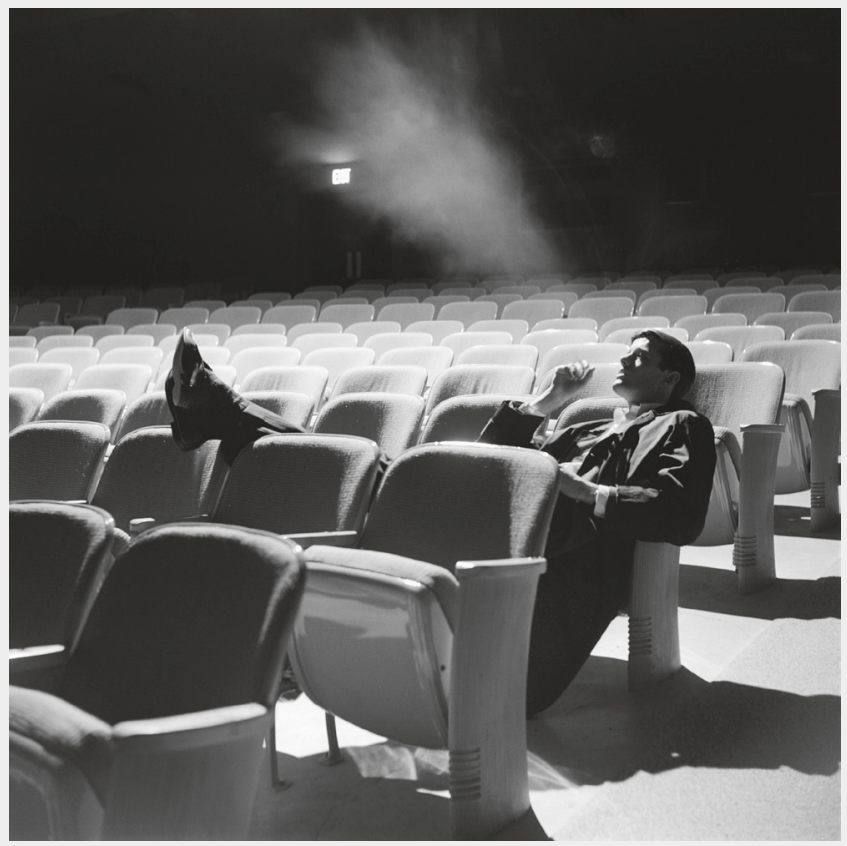

Tim Zumhof

Nicholas K. Johnson (eds.)

Show, Don't Tell

Education and Historical Representations on Stage and Screen in Germany and the USA 


\section{Zumhof / Johnson Show, Don't Tell}


Studien zur Deutsch-Amerikanischen Bildungsgeschichte Studies in German-American Educational History

General Editor Jürgen Overhoff 


\section{Tim Zumhof \\ Nicholas K. Johnson (eds.)}

\section{Show, Don't Tell}

Education and Historical Representations on Stage and Screen in Germany and the USA 
This volume was published in cooperation with the Center for German-American Educational History at the University of Münster.

Titel entstand in Kooperation mit der „Arbeitsstelle für Deutsch-Amerikanische Bildungsgeschichte".

\section{Arbeitsstelle für Deutsch-Amerikanische Bildungsgeschichte}

Dieser Titel wurde in das Programm des Verlages mittels eines Peer-Review-Verfahrens aufgenommen. Für weitere Informationen siehe www.klinkhardt.de.

Bibliografische Information der Deutschen Nationalbibliothek

Die Deutsche Nationalbibliothek verzeichnet diese Publikation in der Deutschen Nationalbibliografie; detaillierte bibliografische Daten sind im Internet abrufbar über http://dnb.d-nb.de.

2020.lg. (C) by Julius Klinkhardt.

Bildnachweis Umschlagseite 1: (C) Francis Miller (1961). Peter Fonda in theater audience seats at Omaha Nebraska Community Playhouse. The LIFE Picture Collection via Getty Images. - The cover photo is used for illustrative purposes only and does not represent an endorsement by the Peter Fonda estate.

Druck und Bindung: AZ Druck und Datentechnik, Kempten.

Printed in Germany 2020.

Gedruckt auf chlorfrei gebleichtem alterungsbeständigem Papier.

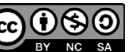

Die Publikation (mit Ausnahme aller Fotos, Grafiken und Abbildungen) ist veröffent-

licht unter der Creative Commons-Lizenz: CC BY-NC-SA 4.0 International

https://creativecommons.org/licenses/by-nc-sa/4.0/

ISBN 978-3-7815-5828-1 Digital

doi.org/10.35468/5828

ISBN 978-3-7815-2397-5 Print 


\section{Table of Contents}

Nicholas K. Johnson and Tim Zumhof

"Are you not entertained?" -

Education, Entertainment, and Historical Representations

on Stage and Screen in Germany and the USA, an Introduction .7

Tim Zumbof

Historical Culture, Public History, and Education

in Germany and the United States of America.

A Comparative Introduction to Basic Concepts and Fields of Research.

Jürgen Overhoff

"Geschichte ist etwas Fließendes."

Lion Feuchtwanger's Changing Understanding of History

and the Role of the Stage: From his Earliest Theatrical Productions

to his Play Waffen für Amerika (1943/44)

Simon Richter

Duell an der Havel:

Fritz von Unruh's Depiction of Eighteenth-Century

Prussian-American Relations

Alissa Rubinstein

The 614th Commandment:

A Documentary Play about how American Jews Feel

about Germany Today

Wolfgang Hochbruck

Living History as an Educational Tool and Method

in North America and Germany

Stephanie Johns

Theatre, Education, and Public History:

Teaching History at the Stratford Festival 
6 Table of Contents

Felix Apel

Hollywood's Influence on the Transmission of Historical Images:

Lars Kraumes' Der Staat gegen Fritz Bauer

Thorsten Carstensen

Learning from John Ford:

History, Geography, and Epic Storytelling in the Works of Peter Handke

Raymond Haberski, Jr.

The Passion of Richard Schickel: What We Expect from War Films

160

Nicholas K. Johnson

"A classroom history lesson is not going to work":

HBO's Conspiracy and Depicting Holocaust Perpetrators on Film

Table of Figures

List of Contributors

Index

Acknowledgements 


\section{Thorsten Carstensen}

\section{Learning from John Ford: History, Geography, and Epic Storytelling in the Works of Peter Handke}

Throughout his career, John Ford staged and narrated American history, generating groundbreaking and gripping films unsurpassed by any other Hollywood director or producer. The images he created have shaped conceptions of American ideals and rituals on both sides of the Atlantic. It was through John Ford's eyes that European cinema-goers in the 1960s and 1970s learned to watch and understand Abraham Lincoln, the vastness of the American West, and the young nation's ideological struggles and internal transformations. But for every viewer, now as then, going to the cinema is also always a process of individual appropriation. What John Ford has to teach about American history ultimately depends on one's own specific questions and interests.

The Austrian writer Peter Handke is among the best-known students of John Ford as an American history teacher. For nearly five decades, Ford's films have been a constant presence in Handke's writings. As I will show in this paper, key attributes of Ford's cinema - his earnest attention to human patterns of life, concentrated narration and perception, pathos of true feelings - can be clearly linked to Handke's own artistic pursuits. The most beautiful films, Handke once said in an interview, confront the viewer with the possibilities "of how one could live one's life." This, he continued, was particularly true of the "attentive, concentrated, pathos-laden films" of John Ford. ${ }^{1}$ Thus, when asked by the organizers of the 2014 Viennale film festival to create a selection of his favorite movies, Handke made sure to include four classic Ford films in his list of 27. Titled "Peter Handke Goes to the Movies," the retrospective featured Young Mr. Lincoln, How Green Was My Valley, The Quiet Man, and The Man Who Shot Liberty Valance. ${ }^{2}$

In his journal Das Gewicht der Welt (1977; The Weight of the World, 1984), Handke notes a maxim that can be applied to his general appropriation of literature, philosophy, visual culture, and even music. This maxim is particularly fitting with regard to his reception of John Ford: "Recapture and preserve [for your own life]

1 Heiko R. Blum. “Gespräch mit Peter Handke," [1970], in Über Peter Handke, ed. by Michael Scharang (Frankfurt am Main: Suhrkamp, 1972), 81; my translation. - I would like to thank Sage Anderson for her invaluable help in translating quotes from Handke’s works. All translations are my own unless otherwise noted.

2 “'Für Momente gerührt': Handke im Kino,” Wien ORF, URL: http://wien.orf.at/news/stories/2674250 (accessed August 10, 2019). 
the circumspectly beautiful life style of the older literature." ${ }^{3}$ For Handke, Ford's films succeed in capturing these beautiful forms of the past that elevate us from what he sees as an oftentimes shapeless present. In Handke's ongoing criticism of artistic expression, Ford's cinema forms an antithesis to the type of seamless and thus inauthentic storytelling based on narrative "tricks" that he sees at work in contemporary American literature. While Handke objects to both Thomas Mann's literary irony and the rather academic narratives of French auteur cinema, he admires Ford's cheerful comedy. According to Handke, Ford's cinema allows the audience to experience the evolution of human relations "image for image and word for word"; upon exiting the cinema, the viewer thinks to himself, "I actually want to be or live like this." 4

In Ford's mythical renderings of the American past, Handke's protagonists discover new possibilities of seeing and interacting with the world. Ford teaches Handke how to tell genuine stories that matter, stories about people trying to reconcile their own ideas and aspirations with those of the wider community and with historical forces that cannot be escaped. ${ }^{5}$ Additionally, returning actors like Henry Fonda and James Stewart convey an ideal of gentle masculinity that blends calm, composure, willingness to act, and strength of character. Handke's exploration of the Fordian universe can be understood as an educational experience, or Bildungserlebnis, in the classic sense of the term. Watching Ford makes Handke aware of how he wants to write and what kind of man he wants to be.

\section{Cinema as Refuge: Handke Goes to the Movies}

There is probably no author other than Handke in modern German-language literature whose work is so prominently marked by a passion for international film. ${ }^{6}$ In letters to his publisher Siegfried Unseld, Handke describes how he would go from theater to theater while in Paris in February 1970, watching one film after another. ${ }^{7}$ Handke is the sort of moviegoer that Walker Percy described in his eponymous 1961 novel (which Handke translated). ${ }^{8}$ For Handke, too, the non-place

3 Peter Handke. The Weight of the World, trans. Ralph Manheim, (New York: Farrar, Straus and Giroux, 1984). 111.

4 Blum, “Gespräch mit Peter Handke," 81.

5 See Alexandra Ambrósio Lopes. "Wirkliche Mythen oder mythische Wirklichkeit? John Ford und Robinson Jeffers in der Prosa von Peter Handke und Botho Strauß," Runa 25.1 (1996): 331.

6 See Lothar Struck. Der Geruch der Filme. Peter Handke und das Kino (Klipphausen/Miltiz: Mirabilis, 2013); for a brief discussion of Handke's reception of John Ford, see 9-12.

7 Letter to Siegfried Unseld, February 8, 1970, in Peter Handke. Siegfried Unseld. Der Briefwechsel, ed. by Raimund Fellinger (Frankfurt am Main: Suhrkamp, 2012), 163.

8 Walker Percy. Der Kinogeher, trans. Peter Handke, (Frankfurt am Main: Suhrkamp, 1980). 
of cinema becomes a place of temporary dwelling, offering him much-needed refuge from the demands and burdens of human company: "As a child, offended by the world around him, he would hide in the corner of a closet; as an adult, he would go to the movies." Accordingly, Joseph Bloch, the protagonist of Handke's 1970 novel Die Angst des Tormanns beim Elfmeter (The Goalie's Anxiety at the Penalty Kick, 1972) is an avid moviegoer; one of his many obsessions is to compare the way people act and speak with what he has seen on screen. ${ }^{10}$ As an early scene in the novel suggests, Bloch, a construction worker who will later commit a murder, regularly retreats to cinemas in order to recover from the onslaught of the signs of reality that he feels compelled to interpret: "It was a beautiful October Day. Bloch ate a hot dog at a stand and then walked past the stalls to a movie theater. Everything he saw bothered him. He tried to notice as little as possible. Inside the theater he breathed freely." 11

Handke's enthusiasm for film is most obvious in his journals from the 1970s, where he recorded impressions such as the audience's "glittering eyeglasses" or old men falling asleep in their seats before the start of the show. ${ }^{12} \mathrm{He}$ also comments on new Hollywood releases such as Taxi Driver, while reflecting on what it means to be a great actor. By the end of 1976, Handke's moviegoing had become a form of addiction with serious repercussions: "almost every film leaves me in a state of lethargy and hopelessness, with a kind of hangover that makes me feel as if I myself and all the people around me were living corpses." ${ }^{13}$ What Handke expresses here is a sense that the "reality" outside the movie theater looks prosaic when compared to the poetic worlds projected on-screen. The emotions evoked by the film quickly give way to disillusionment about the far-from-poetic people on the street. ${ }^{14}$ This rather banal insight leads to the very heart of Handke's aesthetics of the tired gaze of the writer who seeks to discover the good and beautiful in people and things.

While Handke's texts from the 1980s offered few comments on the reception of cinema, the author's interest in contemporary film seems to have been rekindled after his move to Paris in 1990. In a short newspaper feature from that period, Handke not only identifies himself as an emphatic devotee of Hollywood action movies, but also attests to contemporary cinema's ability to tell "new, unheard-of

9 Peter Handke. Die Geschichte des Bleistifts (Salzburg/Vienna: Residenz, 1982), 30.

10 Many critics have noted the novel's cinematic style. See, for instance, Ellen Summerfield. "Die Kamera als literarisches Mittel. Zu Peter Handkes Die Angst des Tormanns beim Elfmeter," Modern Austrian Literature 12.1 (1979).

11 Peter Handke. The Goalie's Anxiety at the Penalty Kick, trans. Michael Roloff (New York: Farrar, Straus and Giroux, 1972), 4.

12 Handke, Weight of the World, 107.

13 Handke, Weight of the World, 211.

14 Handke, Weight of the World, 117. 
stories" that express true emotions. ${ }^{15}$ Since then, cinema has found its way back into Handke's plays and prose works. ${ }^{16}$ This development culminated in 2011 with the novel Der Große Fall (The Great Fall, 2018) whose protagonist, an actor, sets off on a hike from the periphery of Paris to the city center - a hike that is punctuated by numerous cinematic allusions.

Notwithstanding his penchant for "serious" authors like Johann Wolfgang von Goethe, Martin Heidegger, or William Faulkner, Handke's writings have always been informed by the more democratic impulses of popular culture. ${ }^{17}$ In addition to international pop music and German Schlager, he has been particularly fascinated with film as a key medium. In several essays and reviews published in the 1960s, a young Handke explored the aesthetics and politics of both international and domestic cinema. Perhaps best known is his 1968 feuilleton on rural cinemas and the Heimatflm genre, in which he details a longer stay in Burgenland, Austria's easternmost state: "Due to the circumstances," he writes, "I couldn't avoid watching every film I hadn't seen yet, if the respective cinema wasn't too far away." ${ }^{18}$ In this essay, Handke analyzes the narrative strategy of typical Heimatflime before evoking the social significance of cinema in general. For Handke, movie theaters are inherently democratic places offering much-needed shelter from "the cold-hearted, monopolistic, alienating pure culture," and celebrating what he calls the "universally open, humane, heart-warming" Mischkultur.

For Handke, the American director John Ford (1894-1973) is nothing less than an incarnation of this universally accessible Mischkultur. Ford appeared on Handke's personal screen as early as 1971 . In an unpublished journal entry, the author writes: "JOHN FORD: born Maine, 2 children, eyepatch on the left, blue eye, Catholic." 19 Ford still holds the record for winning the most Academy Awards for Best Director (four); Westerns such as Stagecoach (1939) and The Searchers (1956) are routinely counted among the best films ever made. Ford's lifelong fascination with legendary figures from American history such as Wyatt Earp and Abraham Lincoln frequently drew his films back into the distant past to explore the myths

15 Peter Handke. "Die Bilder sind nicht am Ende," in Meine Ortstafeln. Meine Zeittafeln. 1967-2007 (Frankfurt am Main: Suhrkamp, 2007), 573-575.

16 Peter Handke's latest journal, Vor der Baumschattenwand nachts. Zeichen und Anflüge von der Peripherie 2007-2015 (Salzburg/Vienna: Jung und Jung, 2016), which gathers notes spanning the years 2007 to 2015, once again contains observations on going to the movies $(170,172,179)$.

17 Handke has often insisted that his writing is anti-elitist, for example in this short exchange recorded in his journal: "Your writing is elitist." - "How can anyone who has experienced American movies be elitist?" Handke, Weight of the World, 13.

18 Peter Handke. "Vorläufige Bemerkungen zu Landkinos und Heimatfilmen," in Meine Ortstafeln. Meine Zeittafeln. 1967-2007, 527.

19 Peter Handke, Notizbuch, undated [presumably 1971], Schweizerisches Literaturarchiv (SLA-Schafroth A-15-c), 14. ("JOHN FORD: geb. Maine, 2 Kinder, links Augenklappe, blaues Auge, Katholik.") 
and legends firmly rooted in both popular imagination and official history. Intermingled with Ford's concern for the myths of history - or perhaps, one could say, the history of myths - is his deep and abiding love for the West as the cradle of American civilization and a potent quintessence of the American psyche. In short, Ford's cinema offers one of the most important and sustained meditations on the West in American popular culture.

John Ford is among the "artist-ancestors" ("Künstler-Vorfahren") ${ }^{20}$ that Handke's writings continue to evoke, part of a very particular family tree whose branches have grown over years of reading and watching. Handke sees himself as part of a tradition that includes the Pre-Socratics and Chrétien de Troyes as well as the Romanesque stonemasons of the Middle Ages, German-language authors such as Goethe and Adalbert Stifter, the painters Nicolas Poussin, Paul Cézanne and Edward Hopper, the poet-singer Bob Dylan, and the American rock band Creedence Clearwater Revival. This eclectic canon has two primary functions: on the one hand, Handke tries very consciously to recognize the traces of his own work in the foreign; on the other hand, looking into the ancestral gallery also serves to put his own aesthetics to the test. In the case of John Ford, however, ambivalence soon vanishes, and there is an unconditional identification. In the early 1970s, Handke even had an article about Ford attached to the door of his Kronberg residence, as biographer Malte Herwig notes. ${ }^{21}$ Handke felt an attraction to Ford as if they were actually related:

I feel like a grandson of John Ford. I feel like he could be my grandfather, I think I'm like him. If I had had the same power as he did, I'd be just as nasty as he was. Benevolent and detestable. I'd probably be very capricious. He was awfully capricious. An uncannily sensitive person, full of kindness and contempt, the two were mixed in him. ${ }^{22}$

In what follows, I argue that the films of John Ford are central to an understanding of Handke's poetics of place and history. In fact, the connection between Handke and Ford sheds light on what Robert Halsall has called Handke's "awareness of the poetic qualities of all places in the world." ${ }^{23}$ Contrary to what some critics have argued, Handke's fiction is very much informed by a larger economic and historical consciousness. In Ford's cinema, Handke recognizes a striving for epic truthfulness that he has called "the classical." This particular truthfulness is complemented by attention to the universal gestures and movements of human interaction and to details of everyday life, the endearing kindness of things

20 Handke, Geschichte des Bleistifts, 114.

21 Malte Herwig. Meister der Dämmerung. Peter Handke. Eine Biographie, (München: DVA, 2011), 308.

22 Cited in Herwig, Meister der Dämmerung, 309.

23 Robert Halsall. "Den Nicht-Ort gibt es nicht': Handke and the Spirit of Place in Versuch über den Stillen Ort," Gegenwartsliteratur 12 (2013): 141. 
("Lieblichkeit der Dinge"), ${ }^{24}$ which Handke also admires in Homer's epics and Virgil's Georgica. In an interview quoted in Handke's notebooks, Ford once described his epic mode of storytelling in more American terms, associating it with the avoidance of prominent camera movements: ${ }^{25}$ "'You don't like to move the camera much, do you?' - 'No, because it throws the audience off. It says: 'This is a motion picture. This isn't real.' I like to have the audience feel that this is the real thing' (John Ford, 1970)." ${ }^{26}$ For the young Handke in particular, Ford represented a cinema in which "situations and feelings are presented very carefully and gradually, without haste or the need to create an effect." ${ }^{27}$ With this reference to Ford's narrative style, Handke truly hits the mark. Ford's films create the feeling of time standing still through extended, drawn-out sequences, during which the camera seems to develop a contemplative affinity with characters, things, and landscapes, offering "poems to duration," to borrow a phrase from Handke.

\section{John Ford: Epic Storytelling Made in Hollywood}

Peter Handke has repeatedly cast himself as a fatherless figure in search of an ersatz family. His writings continue to revolve around topics such as the search for a father, family reassurance, and the integration into communities. First and foremost is the desire to place oneself within a tradition. It is against this backdrop that the cinema of John Ford constitutes a spiritual offering for Handke, who doggedly envisions himself escaping the "chatter of the world" ("Gerede der Welt") and being absorbed into the "greater now" ("Größere Jetzt") of myth, ${ }^{28}$ as embodied by the Western genre..$^{29}$ As film critic André Bazin argues in one of his seminal essays, the lasting global popularity of the Western is not due to its identifiable imagery and particular plot components, such as bar fights, galloping horses, and deadly shootouts, but rather the fact that it embodies "the essence of cinema." ${ }^{30}$ Bazin

24 Handke, Geschichte des Bleistifts, 84 .

25 See Joseph McBride and Michael Wilmington. John Ford (London: Secker \& Warburg, 1974). There are quite a few veiled references to McBride's biography throughout Handkes's work. See journal entries from 2007 in Vor der Baumschattenwand nachts, 19-20, 22, 24.

26 Handke, Weight of the World, 77.

27 Blum, "Gespräch mit Peter Handke," 81.

28 Peter Handke. Gestern unterwegs. Aufzeichnungen November 1987 bis Juli 1990 (Wien/Salzburg: Jung und Jung, 2005), 155. - See also Weight of the World, 135, where Handke outlines his need for "new, innocent myths culled from everyday life; myths that will help me to begin myselfall over again."

29 On the Western as a genre see John G. Cawelti. Adventure, Mystery, and Romance. Formula Stories as Art and Popular Culture (Chicago: University of Chicago Press, 1976), 192-259.

30 André Bazin. "The Western, or the American Film par excellence," in What is Cinema? ed. by André Bazin, trans. Hugh Gray, vol. 2 (Berkeley: University of California Press, 1971), 141. 
concludes, "Those formal attributes by which one normally recognizes the western are simply signs or symbols of its profound reality, namely the myth." ${ }^{31}$ In its ideal, typical version, the Western represents the epic of the American nation, as French film critic Jean Mitry explains; it could thus be seen as the American equivalent of the Iliad or the Nibelungenlied. ${ }^{32}$ In its classical form, which combines epic narrative with lyrical enthusiasm for landscapes, heroic gestures, and movements, the Western has little concern for complex psychological development. While Ford's protagonists are not portrayed as individual characters in the way they would be in a modern novel, "they already have some psychological density," as Mitry points out: "They are alive, but they are still typecast. They are no longer archetypes, but stereotypes, or rather, highly typified characters." 33

Given that Handke started out as a rather rebellious writer who eagerly deconstructed what he perceived as antiquated literary forms, his enthusiasm for the cinema of John Ford may come as a surprise. His reception of Ford, which combines analytical skill and critical empathy, or Einfühlung, can be traced back to the late 1960s. Handke had his finger on the pulse of the times; in 1970, the French magazine Cahiers du cinéma dedicated an entire issue to Ford's film Young Mr. Lincoln, with several renowned critics reading Ford's oeuvre through a Marxist-structuralist lens. What Handke and Ford have in common is their claim to narrate the world epically. Ford's Westerns, as well as his dramas and war films, engage with the world by looking at the psychology within universal constellations of human existence: rivalry and jealousy; loyalty and service to community; love and family ties; cultivation or civilization of the open spaces of the West; eternal resistance of the oppressed against their oppressors. In other words, Ford's cinema depicts what Handke calls biblical ordinariness or everydayness ("Alltäglichkeit"). ${ }^{34}$ Bazin acknowledges the Western's biblical implications when referring to Ford's Stagecoach as "a fine dramatic illustration of the parable of the pharisee and the publican." ${ }^{35}$ The films are thus also subject to the principle of repetition that underpins Handke's narratives, which are minimal in plot and psychology.

Indeed, Ford's cinema represents an important element of the poetics of truth and beauty that Handke first formulated in his acceptance speech for the 1979 Franz Kafka Prize. Located in the "empire of narrative" ("Reich der Erzählung"), ${ }^{36}$ in

31 Bazin, "The Western, or the American Film par excellence," 142.

32 Jean Mitry. "Über den Western, epischer, dramatischer, psychologischer Western," interview with Gerd Berghoff and Wolfgang Vogel. Filmstudio 37 (1962).

33 Mitry, "Über den Western, epischer, dramatischer, psychologischer Western."

34 Handke, Geschichte des Bleistifts, 35. - On Handke's attention to everydayness as refuge, see Halsall, "Handke and the Spirit of Place," 146.

35 Bazin, "The Western, or the American Film par excellence," 146.

36 Peter Handke. Am Felsfenster morgens (und andere Ortszeiten 1982-1987) (Salzburg/Wien: Residenz, 1998), 11. 
which the individual strands of Handke's secularized poetics of salvation converge, Ford's films make a crucial contribution to solving what Handke has called the "fundamental question," or Grundproblem, underlying his writing: they help the appropriately sensitized viewer rediscover and thus reconnect with an already familiar world. Fictionalization does not obscure reality; on the contrary, it allows for an emphatic experience of things. This is the teaching of cinematic experience that Handke describes in an essay for the Austrian daily Der Standard, titled "Appetite for the World: A Moviegoer's Reflection on this Thing Called Cinema” (1992). Handke recalls a visit several decades ago to a cinema in a suburb of Graz, where Ford's film The Man Who Shot Liberty Valance (1962) was being shown. Although the film was missing "large chunks," so that parts of its plot remained unclear, its impact nevertheless proved powerful. When leaving the cinema, the trees outside rustled "as trees had not rustled for me since my childhood." The film prepared viewers for a fresh appreciation of the familiar:

And now I have yet another word for the world made real by another film: "appetizing." Yes indeed, after watching The Man Who Shot Liberty Valance I had an appetite for the world: for wind, asphalt, seasons, train stations, and not just because of the appetizing food served by substitute waiter James Stewart. ${ }^{37}$

In his journal, Handke describes this phenomenon of art reviving the self as follows: "How do I respond to beauty? I want to set off on a journey - away from what I perceive as beautiful, to create something beautiful of my own." ${ }^{38}$ Reading, especially reading while roaming the countryside, fosters empathic involvement of the self in the world by affirming and intensifying one's presence in the here and now, ${ }^{39}$ as Handke notes on the final page of his travel journal. His protagonists require daily exposure to text, "tägliche Schrift" 40 - not in order to escape the world, but to reconnect with it. ${ }^{41}$ Therefore, his novels' frequent references to medieval epics should not be misunderstood as nostalgic escapism. To give but one example, in Handke's novel In einer dunklen Nacht ging ich aus meinem stillen Haus (1997; On a Dark Night I Left my Silent House, 2000), descriptions of the summer landscape in Hartmann von Aue's Arthurian tale Iwein, written around 1200, help the unnamed pharmacist to recognize "today's summer world," to see it "more clearly before his

37 Peter Handke. "Appetit auf die Welt. Rede eines Zuschauers über ein Ding namens Kino," in Meine Ortstafeln. Meine Zeittafeln. 1967-2007 (Frankfurt am Main: Suhrkamp, 2007), 553.

38 Handke, Am Felsfenster morgens, 12.

39 Handke, Gestern unterwegs, 553.

40 Peter Handke. Die Lehre der Sainte-Victoire (Frankfurt am Main: Suhrkamp, 1980), 9.

41 See Thorsten Carstensen (ed.). Die tägliche Schrift. Peter Handke als Leser (Bielefeld: transcript, 2019). 
eyes." ${ }^{42}$ Reading Iwein allows for "daily travel through space”33 to natural things, refreshing the sense and appreciation of the present in the same way that active recollection does. In a similar fashion, John Ford's cinema whets this appetite for the world. However, his films not only make the present truly real, they also recreate images and perceptions from the viewer's childhood. The rustling of the trees, which links the cinematic experience with the real world upon leaving the movie theater, is therefore doubly coded. On the one hand, it serves to highlight an ideal sense of the here and now; on the other hand, it refers to the kind of quintessential, primal experience of nature that Handke's texts conjure up in ever-new variations. Handke's identification with Ford culminates in the play Die Fahrt im Einbaum (1999; Voyage by Dugout, 2012), in which two filmmakers meet in order to make a film about the war in Yugoslavia. ${ }^{44}$ One of them, bearing the name Luis Machado, is modeled after the Spanish director Luis Buñuel (his name also identifies him as the fictitious grandson of the Spanish poet Antonio Machado, whom Handke has cited as kindred spirit). The other is John Ford, appearing here under the name John O'Hara ${ }^{45}$ Early on in Voyage by Dugout, O'Hara/Ford outlines the very ideals of epic storytelling that Handke has pursued in his own writings. As the American director puts it, "The older I get, the more I find that speed interferes with my experience of something." ${ }^{46}$ Movies, he argues, ought to opt for a slow narration that produces the feeling of time lingering:

"I want a nice chronological narrative, with no deeper meanings or sidelong glances. The telling should be like breathing in and out, whether with the breath of the Great Spirit of the Rockies or of the Ebro or Danube deltas." ${ }^{\text {"47 }}$

"Justice or not, the main thing is the rhythm of our film. If the rhythm is right, the whole film will be right." ${ }^{38}$

"No commentaries. There are no commentaries in my films." ${ }^{39}$

"Spare me the theory. This is supposed to be a feature film." ${ }^{50}$

42 Peter Handke. In einer dunklen Nacht ging ich aus meinem stillen Haus (Frankfurt am Main: Suhrkamp, 1997), 47.

43 Handke, Geschichte des Bleistifts, 176.

44 Peter Handke. "Voyage by Dugout, or The Play of the Film of the War." PAJ: A Journal of Performance and Art 34.2 (2012): 61-99.

45 The two directors' identities are barely masked. In fact, in an early draft of the play, they were explicitly named Ford and Buńuel. For facsimiles of the manuscript, see "Die Fahrt im Einbaum (1999)," Handke online, URL: https://handkeonline.onb.ac.at/node/955 (accessed October 10, 2019).

46 Handke, "Voyage by Dugout," 63.

47 Handke, "Voyage by Dugout," 66.

48 Handke, "Voyage by Dugout," 66.

49 Handke, "Voyage by Dugout," 67.

50 Handke, "Voyage by Dugout," 68. 
O'Hara and Machado have agreed on different roles. While the European, with his "love for secrets, reversed roles, sudden turns," ${ }^{51}$ specializes in psychological depth and will therefore handle monologues and dreams, the American director is tasked with staging straightforward action such as "the fights and the songs" and filming exterior shots and dialogue..$^{52}$ In other words, the John Ford of Voyage by Dugout represents utter exteriority; his films - as well as America, as Handke views it - offer an epic alternative to the academic interiority of European culture.

\section{The Lesson of Young Mr. Lincoln}

References to the cinema of John Ford can be traced throughout Peter Handke's writings since the 1970s. Nowhere, however, is the fabric of biographical and cinematic allusions more tightly woven than in Der kurze Brief zum langen Abschied (1972; Short Letter, Long Farewell, 1974). Handke's novel chronicles the American journey of a nameless young German from coast to coast, focused on his continuous self-reinvention rather than the discovery of a foreign land. When Short Letter, Long Farewell was first published in 1972, many critics were disturbed by the fact that Handke refused to acknowledge West German discourse on the United States - a discourse shaped by the fear that the country might drift into fascism. Critics often quote Reinhard Baumgart's astonishment at the fact that Handke would deliberately ignore contemporary politics and socioeconomic conditions in America. Baumgart considered the fact that the narrator would travel to a "sick" country like the United States in order to be revived by spending his time reading novels and watching films to be a distinct provocation:

Handke's United States by no means coincide with those in the newspaper. There is hardly a trace of Vietnam, and the Harlem ghetto flashes by in eight lines. This man on an educational journey denies us the popular role of the socially engaged tourist. $\mathrm{He}$ obviously prefers to think about himself rather than the big picture. ${ }^{53}$

The critics were right: Short Letter, Long Farewell does not address contemporary political issues. For Handke's narrator, America is a "specular medium;" ${ }^{4}$ it functions as a catalyst that sets in motion "not the exploration of a foreign country but of the person who enters it," as Gerd Gemünden writes. Short Letter, Long Farewell

51 Handke, "Voyage by Dugout," 66.

52 Handke, "Voyage by Dugout," 66.

53 Reinhard Baumgart. "Vorwärts, zurück in die Zukunft," in Über Peter Handke, ed. by Michael Scharang (Frankfurt am Main: Suhrkamp, 1972), 91-92.

54 Gerd Gemünden. Framed Visions. Popular Culture, Americanization, and the Contemporary German and Austrian Imagination (Ann Arbor: University of Michigan Press, 1998), 133-157. 
is a novel of development disguised as a road trip; clearly, the protagonist of this Bildungsroman is more interested in the books he is reading - Gottfried Keller's Der Grüne Heinrich and F. Scott Fitzgerald's The Great Gatsby - and the films he is watching than in the cities and landscapes he passes. As Christoph Parry notes, "References to the cinema abound in the novel to such an extent that it becomes questionable whether the real referent of the work is the actual physical space of America or rather its flat cinematic image." 55 In an interview with Der Spiegel shortly after the publication of his novel, Handke described America as "a dream world in which one is forced to rediscover oneself, in which one must start completely from scratch," continuing:

It's just very difficult to relate the whole story to real America. After all, America is only a pretext for this story, an attempt to find a distant world in which I can become personal. For if I were to situate the same adventure in Europe, I wouldn't be able to think of a place where the objects, where the external world would pose a similar challenge. Likewise, I wouldn't be able to think of a place that would evoke the same depersonalization and alienation in me as America. ${ }^{56}$

What Handke's protagonist learns about America he learns from John Ford, who in this novel takes on the role of the wise old teacher. Consequently, the narrator's journey across the United States comes to an end in Bel Air - or, more precisely, on John Ford's front porch - with the director telling stories and even uttering a surprised "Ach Gott." His desire to visit Ford is sparked by a screening of Young Mr. Lincoln (1939), the director's film about the early life of Abraham Lincoln. Watching the film at a theater in St. Louis, the narrator imagines a future life devoid of the kind of anxiety and self-doubt that have shaped his European existence:

Looking at the images of the past, scenes from the early life of Abraham Lincoln, I dreamed of my own future; the people on the screen prefigured the people I would meet. The longer I watched, the more eager I became to meet only people like those in the picture; then I would never again have to pretend; like them I would be fully present in body and mind, an equal moving among equals, carried along by their motion, yet free to be myself while respecting the freedom of others. ${ }^{57}$

Handke's narrator goes on to relate this ideal of a balanced, peaceful, unconcerned American who is both himself and comfortable with others to various parts of

55 Christoph Parry. Peter Handke's Landscapes of Discourse. An Exploration of Narrative and Cultural Space (Riverside, CA: Ariadne Press, 2003), 77.

56 Hellmuth Karasek. "Ohne zu verallgemeinern," interview with Peter Handke. Die Zeit, March 31, 1972.

57 Peter Handke. Short Letter, Long Farewell, trans. Ralph Manheim. (New York: Farrar, Straus and Giroux, 1974), 114. 
the movie. As Robert Halsall has argued, the passage surely reflects Handke's belief at the time that the surface presence of Hollywood cinema is preferable to the pretensions of interior depth more common in European art film. ${ }^{58}$ At the same time, however, Henry Fonda's Lincoln (Fig. 8) is considered to embody the kind of "equanimity and groundedness" ${ }^{99}$ that both the protagonists of Handke's novels and the alter egos of his journals strive for. While Handke's narrators are often alienated from themselves and others, falling into a state of exaggerated and alarming self-consciousness that leaves them graceless and clumsy, the interaction between characters in Young Mr. Lincoln is seen as ideal: ${ }^{60}$

At one point in the picture, he and an old trapper were riding through the spring landscape on a donkey. Lincoln was wearing a top hat, his feet were almost dragging on the ground, and he was playing a jew's-harp. "What kind of an instrument is that?" the trapper asked. "A jew's-harp," said Lincoln. "Funny people making that kind of music," said the trapper. "But it sounds real purty." The one strumming the jew's-harp, the other wagging his head in time, they were long seen riding through the countryside. ${ }^{61}$

Handke's narrator is equally impressed by the great dignity and humanity conveyed in the film's final scene:

Leaning out of the covered wagon as the family prepared to continue their journey westward, the mother handed Abraham Lincoln a pouch containing his fee. "Take it, it's all I have!" And Lincoln took it! "Thank you, ma’am!" Then he left the settlers and went up on a hill alone. ${ }^{62}$

While Short Letter, Long Farewell pays homage to Ford's oeuvre in general, Young Mr. Lincoln continues to especially fascinate Handke, as a journal entry from the late 1970 s suggests:

This evening reread passages from the Bible, then saw Young Mr. Lincoln again: shaken out of my daily perplexities, but these are not eliminated or thrust aside, rather they are made to shine as something that can and must be borne (Hagar, who, when she thought her child would die of thirst - they had been sent out into the desert - did not go away, but "sat over against him"; and Henry Fonda's Abraham Lincoln, with his

58 Robert Halsall. "Place, Autonomy and the Individual: Short Letter, Long Farewell and A Sorrow Beyond Dreams," in The Works of Peter Handke: International Perspectives, ed. by David N. Coury and Frank Pilipp (Riverside, CA: Ariadne Press, 2005), 54-55.

59 Peter Handke. The Great Fall: A Story, trans. Krishna Winston (London: Seagull Books, 2018), 14.

60 See Rainer Nägele. "Die vermittelte Welt. Reflexionen zum Verhältnis von Fiktion und Wirklichkeit in Peter Handkes Roman 'Der kurze Brief zum langen Abschied'." Jahrbuch der Deutschen Schillergesellschaft 19 (1975): 404.

61 Handke, Short Letter, 116.

62 Handke, Short Letter, 116. 
bodily movements as calm and clear as letters from another Bible); I had to take a deep breath to keep from crying. ${ }^{63}$

Furthermore, in Short Letter, Long Farewell, the narrator's mesmerized reaction to the St. Louis screening of Young Mr. Lincoln is what motivates his decision to visit John Ford in his California home of Bel Air:

I'm going to ask him about his memories of the picture, and whether he still sees Henry Fonda, who's doing soap operas on TV now. I'm going to tell him that I learned about America from that picture, that it taught me to understand history by seeing people in nature, and that it made me happy. I'm going to ask him to tell me what he used to be like and how America has changed since he stopped making pictures. ${ }^{64}$

This excerpt is crucial for understanding Handke's poetics of time and space, as well as his particular attitude towards history. Not only have Ford's movies taught the narrator about America (the mentality of its people and the forces that have shaped the country as an idea); they have also taught him a sense of history beyond dates and political facts - a history that comes to life through the stories of people within their natural surroundings. It is this lesson that Handke has taken to heart, implementing it time and time again in his epics and travelogues since the late 1970s.

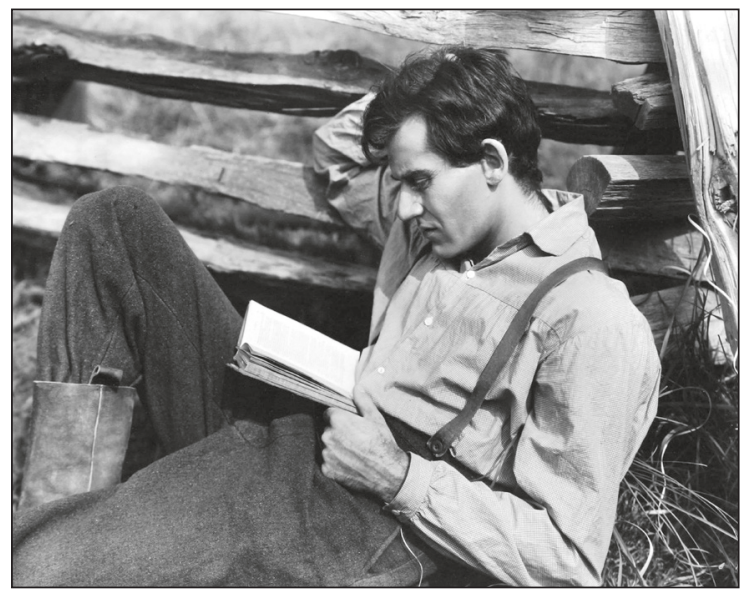

Fig. 8: Henry Fonda as Abraham Lincoln in Ford's Young Mr. Lincoln (1939) (@ akg-images/Album /20TH CENTURY FOX).

63 Handke, Weight of the World, 202. See also Weight of the World, 242-243: "A great actor like Robert de Niro speaks and moves like model and copy in one (he exists, and in existing describes a life); envious thought that with their intense, selfless concern for others such actors are the true writers: their writing is self-explanatory (like Henry Fonda's movements, which appear to me as letters)."

64 Handke, Short Letter, 116. 
In Short Letter, Long Farewell, the protagonist's "pilgrimage" ${ }^{65}$ to Ford's house in California - an episode Handke invented, unlike many of the other travel details that make up the plot - becomes an epiphany. Built in colonial style and surrounded by orange and cypress trees, Ford's home is described as a mythical cradle of storytelling: "For visitors there is a row of wicker chairs; in front of them, footstools covered with Indian blankets. People sitting in those chairs tend to tell stories." ${ }^{66}$ Ford is characterized by the way he communicates. Unlike stereotypical know-it-all Europeans, Ford is careful not to torment his interlocutors with opinions. Instead, he comes across as the quintessential American storyteller:

John Ford repeated a good deal of what I had heard about America [...] during my trip. His ideas were not new, but he backed them up with stories. Sometimes, when you asked a general question, his mind would jump from the general to the particular and he'd talk about incidents in his life and people he'd known. He never judged these people, he simply told us what they had said and done. ${ }^{67}$

The doctrine proclaimed by the fictional John Ford in the final sequence of Short Letter, Long Farewell reveals Handke's personal myth of America as an explicitly positive alternative to what comes across as a rather unappealing European mindset. First and foremost, Ford's America is a country in which Handke's vision of narrative as the predominant form of communication, as described in Weight of the World, has been realized: "The human dignity of the past tense: more and more, storytelling strikes me as the only adequate mode of speech." ${ }^{68}$ According to Handke, Ford's America is also a country that places the value of community above everything else:

"We Americans always say 'we' even when we're talking about our private affairs," said John Ford. "Maybe it's because we see everything we do as part of a common effort. [...] Here in America nobody sulks and nobody crawls into his own shell. We don't long to be alone; when a man's alone, he's contemptible; all he can do is poke around in himself, and when he hasn't anybody but himself to talk with, he dries up after the first word." ${ }^{69}$

While hypersensitive Europeans desire solitude and uniqueness, according to the director's simplified view, Americans share common ideas and goals and thus feel more comfortable being absorbed in larger, epic contexts. "That's why I've always preferred to make pictures about things that happened before my time," concludes the fictional John Ford in Short Letter, Long Farewell. "I don't feel much nostalgia for my own past; what makes me nostalgic is things I never got around to doing

65 Parry, Peter Handke's Landscapes of Discourse, 77.

66 Handke, Short Letter, 159.

67 Handke, Short Letter, 160.

68 Handke, Weight of the World, 96.

69 Handke, Short Letter, 161. 
and places where I've never been." ${ }^{70}$ In Handke's introspective writings, this departure from one's own self often remains wishful thinking. Ford is certainly a muse for Handke, but there is a reason why the American director is given a Spanish sidekick in Voyage by Dugout: Luis Buñuel, creator of the Surrealist classic Un chien andalou (1929), embodies the dreamlike internal dimension of narration, the need for self-enquiry that is always present in Handke's texts. Handke himself has pointed out this second reason for his narrative: "I emerge from my dreams." 71

\section{Sincere Solidarity: Struggle and Community}

John Ford's cinema is rooted in American history, in the history of western expansion - "the momentum of a great nation pushing westward," as one of the intertitles at the beginning of The Iron Horse (1924) puts it with typical Fordian pathos - and the conflict between tradition and modernity that arises from the ideology of manifest destiny. The Iron Horse, Ford's fiftieth film, is the director's first epic Western. The heroic tale of the construction of the first transcontinental railroad provides the historical backdrop for the story of Davy Brandon, a young surveyor for Union Pacific, whose father had been murdered many years before while pursuing his own dream of a rail link between the East and the West. Character and landscape inform and subtly reflect one another as the story moves relentlessly towards the driving of the final spike near Promontory, Utah, on May 10, 1869 a historic event captured by A. J. Russell in his famous "Champagne Photograph" (Fig. 9). In Handke's novel Short Letter, Long Farewell, the narrator offers a short yet comprehensive summary of the film before sharing his viewing experience:

After long years, which were painfully long in the picture as well, for the construction work was shown in great detail, the two lines met at Promontory Point, Utah, and the president drove a golden spike into the last tie. Whereupon the dreamer's son and the president's daughter kissed for the first time since their parting as children. Though I didn't know why, I had felt wretched throughout the picture - shooting pains in my chest, compulsive swallowing, internal soreness, itching, chills - but the moment the spike was driven in and the two fell into each other's arms, I felt their embrace inside me and I stretched inwardly with a sense of infinite relief: my whole body had hungered for the two of them to come together. ${ }^{72}$

70 Handke, Short Letter, 162.

71 Ulrich Greiner, “'Ich komme aus dem Traum," interview with Peter Handke. Die Zeit, February 1, 2006.

72 Handke, Short Letter, 83. 
When John Ford, son of Catholic-Irish immigrants, retraces the history of the American nation in films like The Iron Horse, political aspects naturally play a role. Later, in The Searchers (1956), Ford addresses racism and thus questions the founding myth of the USA. At the heart of Ford's cinema, however, one encounters a constellation focused on the individual and his or her place in the world: the desire to make the land hospitable, to build a home, to create and defend communities. In Ford's cinema, the USA is a country that becomes practically uninhabitable due to the mutual hatred between pioneers and Native Americans; it is a country in which, as Georg Seeßlen writes, Native Americans can no longer live and the arriving white settlers cannot yet. ${ }^{73}$ Ford's films continually address the question of how human communities - and in most cases, these are the communities of white settlers - can persist in the face of history's challenges, and how they can master the immense, hard-to-tame land they find on the North American continent. In his journal, Handke coined a formula for this kind of storytelling that particularly applies to Ford's films: "Western: remembering the dream of proving oneself." 74

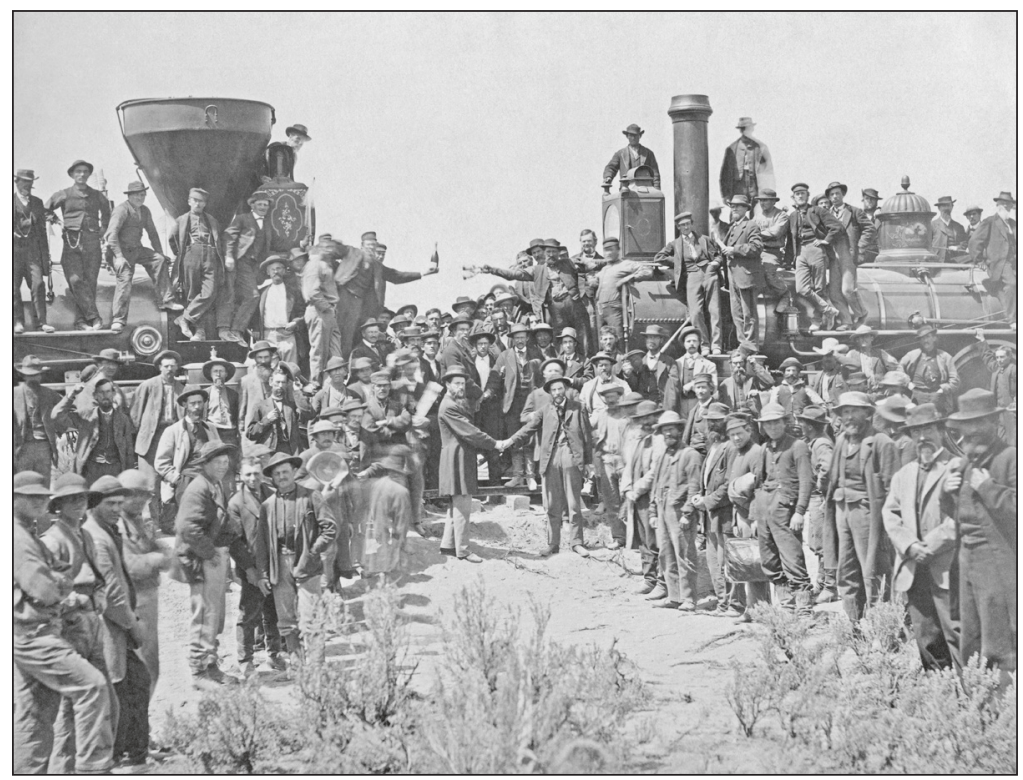

Fig. 9: Andrew J. Russell, Champagne Photograph, East and West shaking Hands at Laying last Rail, May 10, 1869.

73 Georg Seeßlen. Filmwissen: Western. Grundlagen des populären Films (Marburg: Schüren, 2011), 111.

74 Handke, Geschichte des Bleistifts, 9. 
In Ford's films, the motif of proving oneself is linked to that "feeling of community" 75 that Handke's texts continuously evoke. The negative characters in Ford's films are for the most part not ordinary criminals driven by lowly motives; it is because their actions endanger the good of the community that they must be controlled or hunted down. ${ }^{76}$ In this context, the social dance event becomes Ford's leitmotif, which illustrates the new incantation of social cohesion after periods of discord or struggle. ${ }^{77}$ As one of the many "ceremonial gestures"78 that make up his films, dance takes on the form of a solemn ritual designed to authenticate and strengthen community structures. In Two Rode Together, the disturbance of a dance points to a rift in the community. Let us first take a look at the famous dance scene in The Grapes of Wrath (1940), Ford's adaptation of John Steinbeck's bestseller of the same name, published a year earlier. Both the novel and the film are moving portraits of the Depression era, with Ford highlighting the role of the family as an entity that helps nurture identity. Handke recalls the dance scene in Die Lehre der Sainte-Victoire (1980), where he relates Ford to Paul Cézanne and Adalbert Stifter, his two other teachers:

All those present are dancing to ward off a grave menace: driven from place to place by landlessness, they are defending the bit of soil on which they have finally found a home and refuge, from the enemies all around them. Although the dancing is purely a stratagem (while whirling each other about, mother, son, and all the rest exchange wily, vigilant looks), it is nevertheless a dance like other dances (and as none before it), a dance of warmth and solidarity ${ }^{79}$

Handke highlights two aspects in this scene that are equally relevant for his own writings. On the one hand, the dance helps create a symbolic union of the dispossessed, whose claims Ford recognizes through camera angles and editing. On the other hand, the scene also establishes a strong bond between mother and son, who are seen as accomplices, thus skipping what critics have called paternal authority. ${ }^{80}$ Even more famous is the dance sequence in My Darling Clementine (1946), Ford's iconic, mournful Western that has also made several appearances in Handke's work. In fact, it is among the few select topics that the female protagonist of the 2002 novel Der Bildverlust (Crossing the Sierra de Gredos, 2007) is willing to dis-

75 Handke, Geschichte des Bleistifts, 47.

76 Cf. John Baxter. The Cinema of John Ford (New York: A.S. Barnes, 1971), 100.

77 For an account of the role of dancing in Ford's cinema, see Brian Spittles. John Ford (New York: Longman, 2002), 38-39.

78 McBride and Wilmington, John Ford, 28.

79 Peter Handke, Slow Homecoming, trans. Ralph Manheim (New York: Farrar, Straus and Giroux, 1985), 177.

80 Hans Höller. Eine ungewöhnliche Klassik nach 1945. Das Werk Peter Handkes (Berlin: Suhrkamp, 2013), 53. 
cuss with a journalist. ${ }^{81}$ Further references to My Darling Clementine can be found in Immer noch Sturm (2010) and Die schönen Tage von Aranjuez (2012). The film's main character is Wyatt Earp (Henry Fonda), who is hired as a new marshal to restore peace in the fledgling town of Tombstone. The film describes the process of bringing "civilization" to the town by dealing a just punishment to old Clanton and his four sons, who murdered Earp's youngest brother. ${ }^{82}$ Various motifs characteristic of John Ford's cinema converge in the film's central dance episode. After his visit to the barber, the "symbolic high priest of civilization" ${ }^{3}$ who likes to use just a little too much floral eau de toilette on his customers, ${ }^{84}$ Wyatt Earp meets the young Clementine. Together they head down to the church, which is still under construction and due to be consecrated on this very Sunday. Church bells are ringing as the couple gracefully strides towards the town's emergent center, and the Protestant hymn "Shall We Gather at the River?" plays on the soundtrack. ${ }^{85}$ The church may consist of nothing but a foundation and a skeletal bell tower, but the American flag billowing in the wind is already an eloquent sign of community. Following a short dedication ceremony, Wyatt and Clementine join the dance on the church floor. With the temporary connection between the male hero and the female schoolteacher, the symbol of social responsibility found in many Westerns, Ford dissolves the genre's two fundamental forces: the opposing elements of wilderness and civilization. ${ }^{86}$ To quote Robin Wood, their dance embodies, "the union of the natural with the cultivated." 87

While Ford may have attempted to reconstruct Tombstone in an authentic way, the dance sequence goes beyond the scope of the retelling. ${ }^{88}$ Only loosely connected to the actual plot of the film, the entire episode is conceived as an allegory. Here Ford succeeds in what Handke elevates to an essential principle of his own

81 Peter Handke. Crossing the Sierra de Gredos, trans. Krishna Winston (New York: Farrar, Straus and Giroux, 2007), 252.

82 See Jörg Glasenapp. "Der sitzende Marschall. Reinigung und Selbstreinigung in John Fords 'My Darling Clementine.” Weimarer Beiträge 58.1 (2012): 9-22.

83 McBride and Wilmington, John Ford, 96.

84 See Handke's comment in Weight of the World, 238: "The barber stands in the doorway and watches his passing victims."

85 For a discussion of the use of music in My Darling Clementine, see Kathryn Marie Kalinak. How the West Was Sung: Music in the Westerns of John Ford (Berkeley: University of California Press, 2007), 76-90.

86 See Barry Keith Grant. "John Ford and James Fenimore Cooper. Two Rode Together," in John Ford Made Westerns. Filming the Legend in the Sound Era, ed. by Gaylyn Studlar and Matthew Bernstein (Bloomington, IN: Indiana University Press, 2001), 196.

87 Robin Wood. "Shall We Gather at the River?' The Late Films of John Ford," in John Ford Made Westerns. Filming the Legend in the Sound Era, ed. by Gaylyn Studlar and Matthew Bernstein (Bloomington, IN: Indiana University Press, 2001), 32.

88 For a discussion of the dance sequence, see Stefan Fleischer. "A Study through Stills of My Darling Clementine." Journal of Modern Literature 3.2 (April 1973). 
art of storytelling: he transforms concepts and ideas into universal images. For Ford, the communal harmony portrayed in this scene forms the basis of any true civilization. The newborn civilization is taking its first maturity test, as people are coming together to celebrate the fact that they have defied the wild land. It may be a dedication, but there is no praying or preaching; instead, the church becomes a dance floor. As Wood points out, the church floor is the new social center of the village, and Ford's religion is a religion under the banner of community. ${ }^{89}$

\section{Immortalizing Landscapes}

"Above all else, weren't the great poets intimately familiar with place?", Handke once asked in his journal. ${ }^{90}$ This rhetorical question contains a central motif of his late epic narratives, namely the writer's desire to become familiar with places, to absorb "landscapes, locations, rivers, mountain ranges, plain horizons," because "why else would I be travelling?" In an interview with Herbert Gamper, Handke characterized himself as a "writer of places" ("Orts-Schriftsteller"): "For me, places are the spaces, the limitations, that first produce experiences. My starting point is never a story or an event, an incident, but always a place. I don't want to describe the place, I want to narrate it. It brings me the greatest pleasure." ${ }^{2}$ Since the late 1970s, Handke has been concerned with "immortalizing" landscapes, albeit not in the sense of describing them in a realist manner, but rather through "the stories of people." ${ }^{3}$ In his late works, Handke's storytelling is guided by the insight that only places where there are visible traces of human presence - or, more precisely, human labor ${ }^{94}$ - can be activated for his project of long duration:

Nature itself balks at description, as does civilization itself; but I am quite intent on the places where nature and civilization join together into a kind of arcade; intent on components for the White City that can be found everywhere. It is not the small moraine

89 Wood, “'Shall We Gather at the River?' The Late Films of John Ford,” 39. - According to Wood, notwithstanding its rather plain plot, My Darling Clementine possesses an auratic element of truthfulness that the later The Man Who Shot Liberty Valance lacks (24). Thus, My Darling Clementine can be considered "Ford's most harmonious vision of a primitive but developing civilization" (32).

90 Handke, Geschichte des Bleistifts, 168.

91 Handke, Gestern unterwegs, 285.

92 Peter Handke and Herbert Gamper. Aber ich lebe nur von den Zwischenräumen. Ein Gespräch, geführt von Herbert Gamper (Zürich: Ammann, 1987), 19. See also Handke, Weight of the World, 204: "Literature: discover localities that have not yet been claimed by meaning."

93 Handke, Geschichte des Bleistifts, 227.

94 See Wendelin Schmidt-Dengler. "Laboraverimus. Vergil, der Landbau und Handkes Wiederholungen," in Peter Handke. Poesie der Ränder, ed. by Klaus Amann, Fabjan Hafner, and Karl Wagner (Köln, Weimar, Wien: Böhlau, 2006), 158-159. 
lake here in untouched nature that warms my heart, but the river bridge I just leaned upon, or the low stone walls of the pasture landscape. ${ }^{95}$

The reference to man-made stone walls reveals the need to uncover the traces of an ancient material past. It is precisely not untouched nature to which Handke's wandering narrators are drawn. Poetic fantasy is inspired by the abandoned railway tracks in the Spanish plateau or the old cattle tracks of Slovenia. In this interplay of nature and civilization, another history of humanity can be imagined - a history of long duration, always threatened by modernization, war, and displacement. Handke's reflections on narrating space dovetail nicely with elements at the heart of John Ford's cinema. From the very beginning, the cinema of John Ford has been inscribed with the very sense of place ("Ortskenntnis") that Handke considers the writer's true "capital." 96 Ford once said that the Western's claim to an accurate representation of reality is above all connected with its ability to survey the land. ${ }^{97}$ As perhaps the greatest "myth maker" ${ }^{98}$ of American cinema, Ford depicts American geography and history through the stories of people. He was the first director to film in Monument Valley, a place he always described in interviews as his favorite shooting location. ${ }^{99}$ The history of the American West has always been a history of medial representation, and Ford's own appropriation of the American myth is linked to a tradition that extends back into the $19^{\text {th }}$ century, when landscape painters invented the very concept of the "American West." Ford's way of staging both humans and animals against the backdrop of Monument Valley's bizarre rock formations is not only indebted to the landscape paintings of artists such as Albert Bierstadt and Thomas Moran. ${ }^{100}$ As Ford stated in interviews with Peter Bogdanovich, he also drew on the the iconic depictions of frontier life by painter Frederic Remington (1861-1909) when directing his films. ${ }^{101}$

95 Peter Handke. Phantasien der Wiederholung (Frankfurt am Main: Suhrkamp, 1983), 55.

96 Handke, Am Felsfenster morgens, 13.

97 Bill Libby. "The Old Wrangler Rides Again [1964]," in John Ford. Interviews, ed. by Gerald Peary (Jackson: University Press of Mississippi, 2001), 56: "The thing most accurately portrayed in the Western is the land. I think you can say that the real star of my Westerns is the land."

98 Peter Bogdanovich. "A Tribute to John Ford," in John Ford in Focus. Essays on the Filmmaker's Life and Work, ed. by Kevin L. Stoehr and Michael C. Connolly (Jefferson, NC/London, 2008), 12.

99 See Libby, "The Old Wrangler Rides Again," 56: "My favorite location is Monument Valley, which lies where Utah and Arizona merge. It has rivers, mountains, plains, desert, everything the land can offer. I feel at peace there. I have been all over the world, but I consider this the most complete, beautiful and peaceful place on earth."

100 See also Peter Cowie. John Ford and the American West (New York: H.N. Abrams, 2004), 18-22.

101 See also Edward Buscombe. "Painting the Legend. Frederic Remington and the Western," in John Ford Made Westerns. Filming the Legend in the Sound Era, ed. by Gaylyn Studlar and Matthew Bernstein (Bloomington, IN: Indiana University Press, 2001). - In addition to Remington's paintings, Ford also modeled his scenes on Timothy H. O'Sullivan's photographs of the untamed 
Monument Valley forms more than just a backdrop for Ford's stories. As the narrator of Handke's Don Juan (erzählt von ihm selbst) (2004; Don Juan: His Own Version, 2010) claims, the sculpted sandstone buttes of Monument Valley are a perfectly fitting setting for Ford's stories, just "as perhaps the desolate walls of the Italian industrial suburbs" are for Neorealist cinema. ${ }^{102}$ Handke's comparison of the two settings, so different at first glance, reminds the reader that Monument Valley possesses a distinctly architectural quality, like few other landscapes. ${ }^{103}$ The wide, open landscape of the American West is an essential crystallization point for the plot - as Jane Tompkins has indicated, it is an omnipresent feature that every character has to confront. Biblical connotations can hardly be overlooked in many Westerns. Pure, absolute space is a prehistoric fact; man must master it in an everlasting struggle. The first shot of My Darling Clementine alludes to this. We see the inhospitable land stretching flat into the distance, where a wagon train slowly moves forward between the few hills. ${ }^{104}$ The western desert is the New World waiting to be conquered and populated. ${ }^{105}$

\section{Human Dignity}

It is the task of the writer, Handke states in his journal, to devote his energy to carving out human dignity. ${ }^{106}$ This would also be an apt description of Ford's ethics of storytelling. His Westerns imbue their characters with humanity and dignity: Abraham Lincoln, the noble, somewhat awkward young lawyer; the Joad family in The Grapes of Wrath, who leave behind the Oklahoma Dust Bowl hoping to embark on a new life in California; the gallant, reassuring Wyatt Earp in $M y$ Darling Clementine; or the Native Americans in Cheyenne Autumn. This agenda is equally obvious, however, in his attempt to poeticize simple, impoverished workers. Ford's films address the constant endangerment of permanence by the forces of capitalism and by nature itself. Nowhere is this more evident than in The Grapes

American West. O'Sullivan produced his iconic images while accompanying two government surveys of the West in the 1860s and 1870s.

102 Peter Handke. Don Juan: His Own Version (New York: Farrar, Straus and Giroux, 2010), 18. - Handke sees an intrinsic connection between epic storytelling and landscape. As he writes, "Balzac was able to write epic stories because he loved landscapes." Handke, Phantasien der Wiederholung, 66.

103 For a discussion of the monumentality of the landscape of the Western, which seems superhuman and man-made at the same time, see Jane Tompkins. "Landscape: The Language of the Western," in The Big Empty: Essays on Western Landscapes as Narrative, ed. by Leonard Engel (Albuquerque: University of New Mexico Press, 1994), 290.

104 Tompkins, "Landscape: The Language of the Western," 283-285.

105 Tompkins, "Landscape: The Language of the Western," 288.

106 Handke, Geschichte des Bleistifts, 5-6. 
of Wrath, where the Joad family is forced to give up the cultivation of their land. Ford zooms in on the greatness of modest heartland Americans who may end up losing their property due to economic forces beyond their control, but who will never surrender their dignity. As Ma Joad puts it in her final monologue in The Grapes of Wrath: "Rich fellas come up an' they die, an' their kids ain't no good an' they die out. But we keep a'comin'. We're the people that live. They can't wipe us out; they can't lick us. We'll go on forever, Pa, 'cause we're the people."

Likewise, the mineworker epic How Green Was My Valley (1941) links the longing for premodern, rural community to honest hard work. Set in $19^{\text {th }}$-century southern Wales, the film tells the story of the Morgan family and their response to industrialization. How Green Was My Valley locates human dignity in community and family rituals, as the film's masterful opening sequence makes clear. We see the workers leaving the mine and descending into the village, singing proud songs. Meanwhile, the narrator states that this corresponds to the soul of the Welsh people: "Someone would strike up a song, and the valley would ring with the sound of many voices - for singing is in my people as sight is in the eye." Outside the Morgan family home, the mother is already waiting with her outstretched apron, into which the returning men throw their day's wages, one by one. In the next shot, the men are in the garden, gleefully washing the soot from their blackened faces and bodies. Not only do the younger siblings come to their assistance, the scene's humorous climax comes when the mother pours a bucket of water over the head of the father - who is lying in the tub and smoking a pipe - probably as a reminder that dinner is waiting. The voiceover emphasizes the family dimension of this evening ritual:

Then came the scrubbing - out in the back yard. It was the duty of my sister Angharad to bring the buckets of hot water and cold. And I performed what little tasks I could as my father and brothers scrubbed the coal dust from their backs. Most would come off them, but some would stay for life. It is the honorable badge of the coal miner - and I envied it on my father and grown-up brothers. Scrub and scrub, and Mr. Coal would lie there and laugh at you.

A similar scene of communal homecoming after manual labor can be found in Handke's Versuch über die Müdigkeit, a dialogue composed of questions and answers. ${ }^{107}$ After a long day of threshing grain, the men, women, and children of the village sit exhausted but content in quiet harmony in the afternoon sun - a memory that is linked to the ideal of a "people" that bears no national connotations:

107 In an interview, Handke has confirmed the truthfulness of this childhood memory. See Peter Handke im Gespräch mit Hubert Patterer und Stefan Winkler (Graz: Edition Kleine Zeitung, 2012), 55 . 
During my childhood in the late forties and fifties, the arrival of the threshing machine was still an event. The grain was not harvested automatically in the fields - by a combine that takes in the sheaves on one side, while sacks of grain all ready for the miller tumble out on the other side. No, the threshing was done in our home barn by a rented machine that went from farm to farm at harvest time. Its use required a whole chain of helpers. One of these would lift a sheaf of grain out of the farm wagon, which remained in the open because it was much too wide and piled much too high to get into the barn; he would toss it down to the next, who would pass it on [...] to the "big man" in the great rumbling machine which, making the entire barn tremble with its vibrations, would swing the sheaf around and push it gently between the threshing cylinders. Straw came pouring out at the back of the machine, where it formed a pile which the next helper, with a long wooden pitchfork, would pass on to the last links in the chain, the village children, as a rule all present and accounted for $\left[\ldots . .{ }^{108}\right.$

Handke's Versuch über die Müdigkeit, however, is not about romanticizing manual labor as such. The text makes it quite clear that both the noise of the machine and the dust produced by the threshing are difficult to tolerate. What Handke does glorify is the motif of collective toil and the benevolent tiredness enveloping and transfiguring the entire village. Herein lies the parallel not only to the exhausted but happy mining family in How Green Was My Valley, but also to the American settlers in Ford's frontier narratives. Once the threshing is done, a vision of eternal peace settles over the workers and their surroundings:

What silence, not only in the barn, but throughout the countryside; and what light, enfolding rather than blinding you. While the clouds of dust settled, we gathered in the farmyard on shaking knees, reeling and staggering, partly in fun. Our legs and arms were covered with scratches; we had straw in our hair, between our fingers and toes. And perhaps the most lasting effect of the day's work: the nostrils of men, women, and children alike were black, not just gray, with dust. Thus we sat - in my recollection always out of doors in the afternoon sun - savoring our common tiredness whether or not we were talking, some sitting on a bench, some on a wagon shaft, still others off on the grass of the bleaching field - the inhabitants of the whole neighborhood, regardless of generation, gathered in episodic harmony by our tiredness. ${ }^{109}$

In Handke's works, the utopian idea of non-alienating labor ${ }^{110}$ is contrasted with the real-life situation of powerless folks. But the dream remains, and it is constantly renewed through storytelling.

108 Peter Handke. Essay on Tiredness, trans. Ralph Manheim, in The Jukebox and Other Essays on Storytelling, trans. Ralph Manheim and Krishna Winston (New York: Farrar, Straus and Giroux, 1994), 13-14.

109 Handke, Essay on Tiredness, 14-15.

110 Höller, Eine ungewöhnliche Klassik nach 1945, 54. 
Handke has always been concerned with simple people who have been forgotten by the system - and their will to survive. His interest in the Western, which he associates with enduring "great hardships," 111 can also be traced back to the fact that he sees himself as "a man without a history, from a family without a history." 112 In an interview with Ulrich Greiner, Handke describes himself as a "follower of the ancestor cult," expressing his wish to engage in a conversation with his ancestors "because they were great people who perished." 113 Having grown up in a working-class family, Handke derives his authority as a writer not least from the responsibility of honoring his ancestors by writing about them. When Filip Kobal embarks on his journey to Slovenia in Die Wiederholung (1986; Repetition, 1988), he does so in the footsteps of his brother Gregor, who went missing in action during World War II. This journey varies the structure of the Bildungsroman, as the novel deals primarily with the development of the protagonist on a biographical level. The travelogue is linked to a reappraisal of the geography of childhood. This stems from the need "to represent the rights of the ancestors" and thus "to honor the dead," 114 as the journal puts it. Filip Kobal repeats the geography of childhood in order "to prove myself in my own way worthy of my forebears and to save what they stood for." ${ }^{115}$ Even Wunschloses Unglück (1972; A Sorrow Beyond Dreams, 1974), the autobiographical novella in which Handke recapitulates his mother's life and suicide, is rooted in the historical awareness of having to give voice to the dispossessed, albeit in retrospect:

Well then, it began with my mother being born more than fifty years ago in the same village where she died. At that time all the land that was good for anything in the region belonged either to the church or to noble land-owners; part of it was leased to the population, which consisted mostly of artisans and small peasants. The general indigence was such that few peasants owned their land. For practical purposes, the conditions were the same as before 1848; serfdom had been abolished in a merely formal sense. ${ }^{116}$

It is this overlapping of geography, class consciousness, and personal family myth that accounts for Handke's persistent reception of Ford's cinema. Given this constellation, Ford's world is not entirely different from the context of Handke's enthusiastic reception of medieval Romanesque architecture. ${ }^{117}$ The latter's pilgrim-

111 Handke, Weight of the World, 8.

112 Handke, Weight of the World, 135.

113 Greiner, “'Ich komme aus dem Traum," interview with Peter Handke.

114 Handke, Am Felsfenster morgens, 320 and 218.

115 Peter Handke. Repetition, trans. Ralph Manheim (London: Methuen, 1988), 214.

116 Peter Handke. A Sorrow Beyond Dreams: A Life Story, trans. Ralph Manheim, with an introduction by Jeffrey Eugenides (New York: Farrar, Straus and Giroux, 2002), 9.

117 I have explored this topic in my book, Romanisches Erzählen. Peter Handke und die epische Tradition (Göttingen: Wallstein, 2013). 
age to Romanesque churches and mountain cloisters can also be understood as an attempt at sublimation. The sense of an existential lack of origin is overcome by the appropriation of an architectural epoch whose remains seem to preserve the symbolic heritage of Handke's own ancestors. While Handke views the Gothic as "royal propaganda" - or architectural representation of the rulers - he is eager to transfigure the Romanesque era as his village home ("Dorfheimat"), in which the memory of his ancestors ("das Gedächtnis all der Unsern, der Vorfahren") is preserved. ${ }^{118}$ Just as "country churchyards," like rural cinemas, convey to him an "idea of 'the people'," 119 the Romanesque sculptures found in village churches become a symbol of resistance to the rational modernity of metropolitan areas: preserved in them is the hope that "a completely different humanity" 120 may be possible.

\section{Poets and Cowboys: Writing is an Adventure}

It is typical of Peter Handke's appropriation of art forms and eras that his reception of John Ford's cinema does not follow a scholarly route; instead, it stems from the desire to identify with and receive validation from an artist he considers a teacher. In Short Letter, Long Farewell, the modeling of real life after Fordian aesthetics is illustrated towards the very end, when the protagonist catches himself blending with one of Ford's characters: "Expecting a story, we leaned forward a little; I realized that I was imitating the gesture of a character in one of his pictures who without shifting his position cranes his long neck over a dying man to see if he's still alive." 121

One question, however, remains to be asked: Are we to imagine Peter Handke's male protagonists as heroes in the sense of the American Western? Just as in Ford's Westerns, where the future well-being of civilization is often based on the willingness of men to resist domestication by women, Handke's narrators also come across as lonely riders who excel in imagining cheerful togetherness, but still wake up alone in bed, like the writer protagonist in Die morawische Nacht (2008; The Moravian Night, 2016). In fact, Handke's Versuch über den Pilznarren (2013; A Fool for Mushrooms. An Essay. A Story in Itself) spells out the parallels between the isolated writer and the watchful sheriff:

Yet another film came to mind before I headed over to my desk here. It was not the title, it was one of the opening scenes, if not the opening scene. It was (once again...) a West-

118 Handke, Gestern unterwegs, 87, 296.

119 Handke, Weight of the World, 208.

120 Handke, Gestern unterwegs, 540.

121 Handke, Short Letter, 167. 
ern, by (you guessed it) John Ford, and at the beginning of the story, James Stewart, as the famous Sheriff Wyatt Earp - long after his now legendary Tombstone adventures, it seems - is sitting on the porch of his sheriff's office in the southern Texan? sun, idle and dreamy as only James Stewart can be, by all appearances peacefully and decisively letting nothing but time pass under the brim of a hat pulled halfway over his eyes, enviable and inspiring at the same time. ${ }^{122}$

This excerpt from Versuch über den Pilznarren refers to Two Rode Together (1961), a critical and commercial failure that Ford himself called "the worst piece of crap I've directed in twenty years." ${ }^{123}$ As several journal entries indicate, Handke watched the film as early as 1976; he discusses Ford's cinematographic style, citing the famous five-minute, two-shot sequence from Two Rode Together, in which Richard Widmark and James Stewart sit by the river. ${ }^{124}$ Stewart's character exhibits composure and calm determination throughout the film, along with organic belonging in the here and now, attentiveness, and the ability to be idle: Handke's characters constantly long for these qualities. Handke has often described this condition as "having time" - a sense of existential freedom (and thus individual authority) expressed in a particular gait, a certain gaze. ${ }^{125}$ James Stewart embodies an almost "cosmic" agreement that also helps Handke's mushroom seeker find mushrooms where others would not - a quality that seems "downright derisive" to outsiders. ${ }^{126}$ Like Handke's Don Juan, he is a "master of his own time." 127 By quoting the scene in which Stewart is seen sitting on the veranda of his sheriff's office, "idle and dreamy as only James Stewart can be," Handke mobilizes Ford's cinema for his critique of modernity's acceleration. As a master of his own time, Stewart personifies serenity, and it is precisely this serenity that places both the subject himself and the things around him in a special light. Having time provides the human being with heightened attention and awareness; a presence of mind Handke calls it the "tired gaze" - with which he does justice to his environment:

But then, otherwise it wouldn't be a Wild West story, the beginning of a new adventure, at first rather reluctantly and - do I remember correctly? - lured only by money, and headed northwards rather than westwards. Subsequently, however, and especially at the end of the story: the intuitive intervention, the gentle attention, the silently helpful

122 Peter Handke. Versuch über den Pilznarren (Berlin: Suhrkamp, 2013), 8-9.

123 John Ford, as quoted in Dan Ford. Pappy: The Life of John Ford (New York: Da Capo Press, 1998), 290. - Film critic R. M. Hodgens summed it up neatly when he claimed that the only element Ford had successfully developed in this film was "the rather tacky humor." R. M. Hodgens, review of Two Rode Together, by John Ford, Film Quarterly 15.1 (1961): 56.

124 Peter Handke, Notizbuch, January 17-22, 1976, Österreichisches Literaturarchiv (ÖLA SPH/ LW/W9), 9 and 24.

125 See Carstensen, Romanisches Erzählen, 189-196.

126 Handke, Versuch über den Pilznarren, 49.

127 Handke, Don Juan: His Own Version, 33 
presence of mind, as again only James Stewart radiated and continues to radiate it. Not only "Two Rode Together," according to the title of the film, where the second rider is Richard Widmark: more people rode together in the end, many, if not (almost) all. ${ }^{128}$

Handke's summary of Ford's Two Rode Together can be read as a metapoetic commentary on his own work. Each day, as he makes his way to his desk, the writer is faced with the challenges of a different kind of quest or conquest. Reluctantly at first, but soon embodying the "gentle attention" of a James Stewart, he embarks on his day's labor. Handke's protagonists treat writing as a "serious" adventure 129 that will allow them to imagine an alternative community, uniting the writer-cowboy, his characters, and his readers. As Handke puts it, more people will ride together in the end - many, if not all.

\section{Works Cited}

Ambrósio Lopes, Alexandra. "Wirkliche Mythen oder mythische Wirklichkeit? John Ford und Robinson Jeffers in der Prosa von Peter Handke und Botho Strauß.” Runa 25.1 (1996): 327-336.

Baumgart, Reinhard. "Vorwärts, zurück in die Zukunft." in Über Peter Handke, ed. by Michael Scharang (Frankfurt am Main: Suhrkamp, 1972), 90-94.

Baxter, John. The Cinema of John Ford. New York: A.S. Barnes, 1971.

Bazin, André. "The Western, or the American Film par excellence," in What is Cinema?, trans. by Hugh Gray, vol. 2 (Berkeley: University of California Press, 1971), 140-148

Blum, Heiko R. "Gespräch mit Peter Handke [1970]," in Über Peter Handke, ed. by Michael Scharang (Frankfurt am Main: Suhrkamp, 1972), 79-84.

Bogdanovich, Peter. "A Tribute to John Ford." in John Ford in Focus. Essays on the Filmmaker's Life and Work, ed. by Kevin L. Stoehr and Michael C. Connolly (Jefferson, NC/London, 2008), 7-13.

Buscombe, Edward. "Painting the Legend. Frederic Remington and the Western," in John Ford Made Westerns. Filming the Legend in the Sound Era, ed. by Gaylyn Studlar and Matthew Bernstein (Bloomington, IN: Indiana University Press, 2001), 154-168.

Carstensen, Thorsten (ed.). Die tägliche Schrift. Peter Handke als Leser. Bielefeld: transcript, 2019.

Carstensen, Thorsten. Romanisches Erzählen. Peter Handke und die epische Tradition. Göttingen: Wallstein, 2013.

Cawelti, John G. Adventure, Mystery, and Romance. Formula Stories as Art and Popular Culture. Chicago: University of Chicago Press, 1976.

Cheyenne Autumn. John Ford, dir. (USA, 1964).

Cowie, Peter. John Ford and the American West. New York: H.N. Abrams, 2004.

Fellinger, Reimund (ed.). Peter Handke. Siegfried Unseld. Der Briefwechsel, Frankfurt am Main: Suhrkamp, 2012.

Fleischer, Stefan. "A Study through Stills of My Darling Clementine." Journal of Modern Literature 3.2 (1973): 241-252.

Ford, Dan. Pappy: The Life of John Ford. New York: Da Capo Press, 1998.

Gemünden, Gerd. Framed Visions. Popular Culture, Americanization, and the Contemporary German and Austrian Imagination. Ann Arbor: University of Michigan Press, 1998.

128 Handke, Versuch über den Pilznarren, 9.

129 Handke, Versuch über den Pilznarren, 11. 
Glasenapp, Jörg. "Der sitzende Marschall. Reinigung und Selbstreinigung in John Fords 'My Darling Clementine.” Weimarer Beiträge 58.1. (2012): 9-22.

Grant, Barry Keith. "John Ford and James Fenimore Cooper. Two Rode Together," in John Ford Made Westerns. Filming the Legend in the Sound Era, ed. by Gaylyn Studlar and Matthew Bernstein (Bloomington, IN: Indiana University Press, 2001), 193-219.

The Grapes of Wrath. John Ford, dir. (USA, 1940).

Greiner, Ulrich. "Ich komme aus dem Traum'." Interview with Peter Handke. Die Zeit, February 1, 2006.

Halsall, Robert. "'Den Nicht-Ort gibt es nicht': Handke and the Spirit of Place in Versuch über den Stillen Ort." Gegenwartsliteratur 12 (2013): 139-164.

Halsall, Robert. "Place, Autonomy and the Individual: Short Letter, Long Farewell and A Sorrow Beyond Dreams," in The Works of Peter Handke: International Perspectives, ed. by David N. Coury and Frank Pilipp (Riverside, CA: Ariadne Press, 2005), 46-79.

Handke, Peter. The Great Fall: A Story, trans. by Krishna Winston. London: Seagull Books, 2018.

Handke, Peter. Vor der Baumschattenwand nachts. Zeichen und Anflüge von der Peripherie 2007-2015. Salzburg/Wien: Jung und Jung, 2016.

Handke, Peter. Versuch über den Pilznarren. Berlin: Suhrkamp, 2013.

Handke, Peter. "Voyage by Dugout, or The Play of the Film of the War." PAJ: A Journal of Performance and Art 34.2 (2012): 61-99.

Handke, Peter. Don Juan: His Own Version. New York: Farrar, Straus and Giroux, 2010.

Handke, Peter. "Vorläufige Bemerkungen zu Landkinos und Heimatfilmen," in Meine Ortstafeln. Meine Zeittafeln. 1967-2007 (Frankfurt am Main: Suhrkamp, 2007), 527-533.

Handke, Peter. "Appetit auf die Welt. Rede eines Zuschauers über ein Ding namens Kino," in Meine Ortstafeln. Meine Zeittafeln. 1967-2007 (Frankfurt am Main: Suhrkamp, 2007), 550-554.

Handke, Peter. "Die Bilder sind nicht am Ende," in Meine Ortstafeln. Meine Zeittafeln. 1967-2007 (Frankfurt am Main: Suhrkamp, 2007), 573-575.

Handke, Peter. Gestern unterwegs. Aufzeichnungen November 1987 bis Juli 1990. Wien/Salzburg: Jung und Jung, 2005.

Handke, Peter. A Sorrow Beyond Dreams: A Life Story, trans. by Ralph Manheim, with an introduction by Jeffrey Eugenides. New York: Farrar, Straus and Giroux, 2002.

Handke, Peter. Die Fahrt im Einbaum oder Das Stück zum Film vom Krieg. Frankfurt am Main: Suhrkamp, 1999.

Handke, Peter. Am Felsfenster morgens (und andere Ortszeiten 1982-1987). Salzburg/Wien: Residenz, 1998.

Handke, Peter. In einer dunklen Nacht ging ich aus meinem stillen Haus. Frankfurt am Main: Suhrkamp, 1997.

Handke, Peter. Essay on Tiredness, trans. by Ralph Manheim, in The Jukebox and Other Essays on Storytelling, trans. by Ralph Manheim and Krishna Winston (New York: Farrar, Straus and Giroux, 1994), 3-44.

Handke, Peter. Repetition, trans. by Ralph Manheim. London: Methuen, 1988.

Handke, Peter and Herbert Gamper. Aber ich lebe nur von den Zwischenräumen. Ein Gespräch, geführt von Herbert Gamper. Zürich: Ammann, 1987.

Handke, Peter. Slow Homecoming, trans. by Ralph Manheim. New York: Farrar, Straus and Giroux, 1985.

Handke, Peter. The Weight of the World, trans. by Ralph Manheim. New York: Farrar, Straus and Giroux, 1984.

Handke, Peter. Phantasien der Wiederholung. Frankfurt am Main: Suhrkamp, 1983.

Handke, Peter. Die Geschichte des Bleistifts. Salzburg/Wien: Residenz, 1982.

Handke, Peter. Die Lehre der Sainte-Victoire. Frankfurt am Main: Suhrkamp, 1980. 
Handke, Peter. Notizbuch, January 17-22, 1976. Österreichisches Literaturarchiv (ÖLA SPH/LW/ W9).

Handke, Peter. Short Letter, Long Farewell, trans. by Ralph Manheim. New York: Farrar, Straus and Giroux, 1974.

Handke, Peter. The Goalie's Anxiety at the Penalty Kick, trans. by Michael Roloff. New York: Farrar, Straus and Giroux, 1972.

Handke, Peter. Notizbuch, undated [presumably 1971]. Schweizerisches Literaturarchiv (SLA-Schafroth A-15-c).

Herwig, Malte. Meister der Dämmerung. Peter Handke. Eine Biographie. München: DVA, 2011.

Hodgens, R. M. Review of Two Rode Together, by John Ford. Film Quarterly 15:1 (1961): 56.

Höller, Hans. Eine ungewöhnliche Klassik nach 1945. Das Werk Peter Handkes. Berlin: Suhrkamp, 2013.

How Green Was My Valley. John Ford, dir. (USA, 1941).

The Iron Horse. John Ford, dir. (USA, 1924).

Kalinak, Kathryn Marie. How the West Was Sung: Music in the Westerns of John Ford. Berkeley: University of California Press, 2007.

Karasek, Hellmuth. "Ohne zu verallgemeinern.” Interview with Peter Handke. Die Zeit, March 31, 1972.

Libby, Bill. “The Old Wrangler Rides Again” [1964], in John Ford. Interviews, ed. by Gerald Peary (Jackson: University Press of Mississippi, 2001), 46-57

McBride, Joseph and Michael Wilmington. John Ford. London: Secker \& Warburg, 1974.

Mitry, Jean. “Über den Western, epischer, dramatischer, psychologischer Western.” Interview with Gerd Berghoff and Wolfgang Vogel. Filmstudio 37 (1962).

My Darling Clementine. John Ford, dir. (USA, 1946).

Nägele, Rainer. "Die vermittelte Welt. Reflexionen zum Verhältnis von Fiktion und Wirklichkeit in Peter Handkes Roman 'Der kurze Brief zum langen Abschied'.” Jahrbuch der Deutschen Schillergesellschaft 19 (1975): 398-418.

Parry, Christoph. Peter Handke's Landscapes of Discourse. An Exploration of Narrative and Cultural Space. Riverside, CA: Ariadne Press, 2003.

Schmidt-Dengler, Wendelin. "Laboraverimus. Vergil, der Landbau und Handkes Wiederholungen," in Peter Handke. Poesie der Ränder ed. by Klaus Amann, Fabjan Hafner and Karl Wagner (Köln, Weimar, Wien: Böhlau), 155-165.

Seeßlen, Georg. Filmwissen: Western. Grundlagen des populären Films. Marburg: Schüren, 2011.

Spittles, Brian. John Ford. New York: Longman, 2002.

Stagecoach. John Ford, dir. (USA, 1939).

Struck, Lothar. Der Geruch der Filme. Peter Handke und das Kino. Klipphausen/Miltiz: Mirabilis, 2013.

Summerfield, Ellen. "Die Kamera als literarisches Mittel. Zu Peter Handkes Die Angst des Tormanns beim Elfmeter." Modern Austrian Literature 12.1 (1979): 95-112.

The Searchers. John Ford, dir. (USA, 1956).

Tompkins, Jane. "Landscape: The Language of the Western." In The Big Empty: Essays on Western Landscapes as Narrative, ed. by Leonard Engel (Albuquerque: University of New Mexico Press, 1994), 283-301.

Two Rode Together. John Ford, dir. (USA, 1961).

Wood, Robin. "'Shall We Gather at the River?' The Late Films of John Ford," in John Ford Made Westerns. Filming the Legend in the Sound Era, ed. by Gaylyn Studlar and Matthew Bernstein (Bloomington, IN: Indiana University Press, 2001), 23-41.

Young Mr. Lincoln. John Ford, dir. (USA, 1939). 